\title{
DIGITAL PROCESSING OF OPTICAL EMISSION SPECTRA OF MAGNETRON SPUTTERING PLASMA SYSTEM
}

\author{
I.A. Afanasieva ${ }^{I}$, S.N. Afanasiev ${ }^{1,2}$, N.A. Azarenkov ${ }^{I}$, V.V. Bobkov ${ }^{I}$, V.V. Gritsyna ${ }^{1}$, \\ Yu.E. Logachev ${ }^{1}$, I.I. Okseniuk ${ }^{1}$, A.A. Skrypnyk ${ }^{1}$, D.I. Shevchenko ${ }^{1}$, V.M. Chornous ${ }^{3}$ \\ ${ }^{1}$ V.N. Karazin Kharkiv National University, Kharkov, Ukraine; \\ ${ }^{2}$ National Science Center “Kharkov Institute of Physics and Technology”, Kharkov, Ukraine; \\ ${ }^{3}$ Ivano-Frankivsk National Technical University of Oil and Gas, Ivano-Frankivsk, Ukraine \\ E-mail: plip@karazin.ua
}

To solve the actual problem of the analysis of the sputtered particles radiation during coating deposition in a magnetron sputtering system, a digital technique was proposed for processing the emission spectra of the discharge plasma. A graphic OSA application has been created, which allows obtaining qualitative and quantitative characteristics of the magnetron discharge plasma. The obtained information about the distribution of excited particles along the direction parallel to the axis of the magnetron discharge permits one to control the mode of the discharge operation and, as a consequence, the properties of the deposited coatings.

\section{INTRODUCTION}

Magnetron sputtering systems are highly efficient devices for depositing coatings from metals, alloys, oxides, and nitrides [1].

The technology of deposition of functional coatings can be significantly improved if, during the process of film formation on the object surface, it is possible to control the elemental composition of the particles deposited on the product that is determined by the chemical properties of the sputtered cathode and the atmosphere in the working chamber.

Optical spectrometry is widely used to analyze the composition of plasma of gas discharge [2,3]. One of the methods for radiation detecting, when using optical spectrometry, is the photographic technique. The undoubted advantage of this system for registration the emission of sputtered excited particles is the possibility to obtain the integral characteristics of the entire spectrum under study in a wide range of wavelengths along the height of the radiation. This is important because the distribution of particles in the plasma depends on the mode of operation of the discharge and, finally, determines the quality of the coating and the efficiency of its application. Monitoring the spectrum spatial changes during coating deposition allows to control the mode of operation of the discharge and the properties of the coating.

A limiting factor for the wide application of a photographic registration system is the use of photographic plates or photographic films as recording elements, which require multi-stage specific and timeconsuming processing of photographic material [4], during which a high experimental error is not excluded. The transition to film recording of information using charge coupling devices (CCD sensor) [5] and modern computer technologies allows us to speed up significantly the process of obtaining physical information and analyze the optical emission spectra of magnetron discharge plasma directly on a computer without using additional means of processing photo-film materials.

The purpose of this work is to create a multifunctional interactive GUI-application OSA
(Optical Spectrum Analyzed) to obtain such characteristics of the plasma emission spectrum of a magnetron discharge as the wavelength of a recorded line and the spatial distribution of its intensity.

\section{DIGITAL OPTICAL IMAGE PROCESSING PROCEDURE}

As test images, digitized photographic frame data of the emission spectra obtained earlier [6] were used in the study of the MSS using a photo-film measurement technique. Frames scanning was performed on a special slide scanner of high resolution photographic films (size $-5040 \times 3360$ pixels) with obtaining digital images with the extension *.jpg. It should be noted that after digitizing the image is positive, unlike film, where the image is reversed.

In a computer, a digital image is a visible field that represents only a certain function of the distribution of intensity or color on a two-dimensional plane. From a mathematical point of view, a digital image is a twodimensional matrix $f[x, y]$, where $x$ and $y$ are an integer describing the number of the column or row of the matrix in which this element is located. Each element of a digital image (a cell of a rectangular matrix) - a pixel of the $f[x, y]$ matrix has a scalar integer value proportional to the value of the intensity distribution function $\mathrm{I}[\mathrm{x}, \mathrm{y}]$ at a given point of the plane. Therefore, obtaining experimental data can be obtained only as a result of applying a number of image processing and analysis procedures, which we must program ourselves using ready-made modules that are available in wellknown packages.

The development of the OSA application was carried out using the Python programming language [7] on the Tkinter graphics library (toolkit interface) platform using a stack of additional modules such as PIL, NumPy, SciPy, and Matplotlib. Python is a high-level general-purpose programming language. The advantages of the Python programming language as the dominant platform in scientific research are the following: simplicity of syntax, high learning speed due to simple syntax, high power with simple syntax, a large number of free modules and libraries, simple installation 
of modules and libraries during development, and the availability of detailed documentation like on the language itself, and on the modules. In Fig. 1 is a screenshot of the OSA application.

The OSA application has a scenario cycle of events polling generated by user actions such as keyboard input, keystrokes, or pointer movement. For each potential event, a function is assigned that will be called when this event occurs. For each function, it is possible to create a specific graphic component (widget) that can be placed on the application canvas.

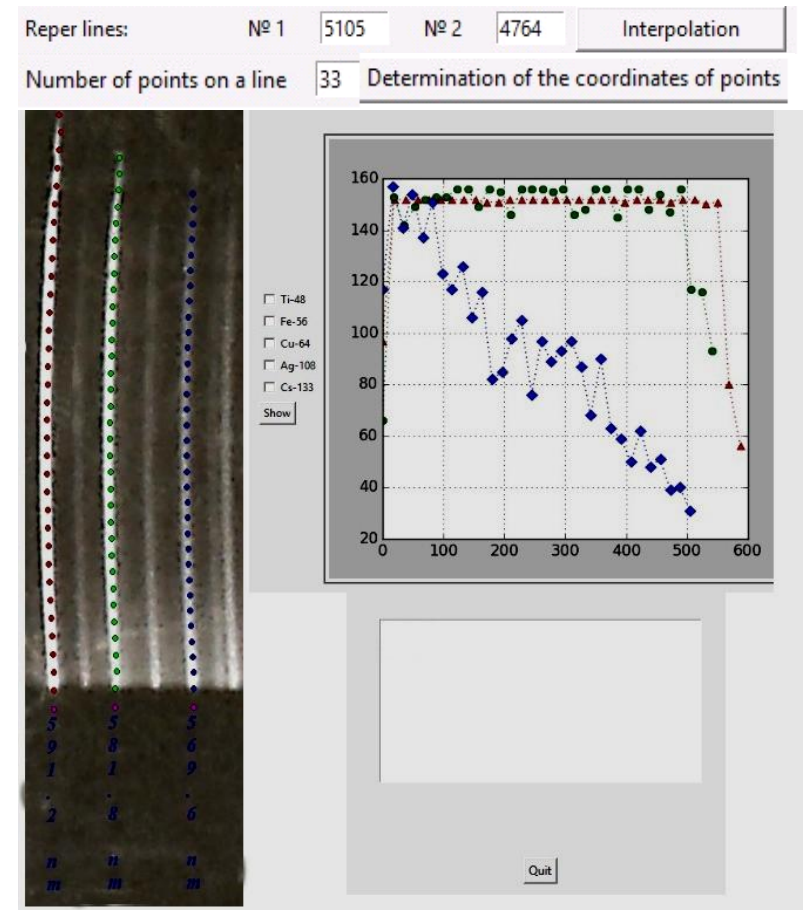

Fig. 1. The view of the graphic application for processing the glow spectrum of a discharge plasma

The basic procedures and algorithms embedded in the OSA application for processing of optical spectra include:

- access to the numerical matrix of pixels of the scanned image (*.jpg);

- the transition from the pixel coordinate system $[\mathrm{x}, \mathrm{y}]$ of a digital photo to the coordinate system of the film;

- determination of the wavelength of an arbitrary spectral line on a digital image using an interpolation function based on a graduated scale;

- determination of the distribution of the intensity of the glow of the spectral line along its height by the method of determining the coordinates of points using a piecewise-linear approximation and assigning them the proper intensity;

- output of the spectral line intensity distribution both in the form of a graph and in the form of a numerical matrix for further processing. Also, it should be noted some variation in the definition of archival data - it is possible to simultaneously process several lines in the spectrum. This is very informative both in the preliminary visual analysis and in the further analysis by other external sources.

\section{OSA APPLICATION FUNCTIONALITY}

Information on the wavelengths of spectral lines presented in the optical spectrum allows us to determine the qualitative composition of the plasma of the magnetron discharge [8]. Therefore, the first step in processing of a digital image is determining the wavelength of a particular line and its interpretation that is determining the presence of particles in a particular charge and energy state belonging to the corresponding chemical element. It should be noted that the interpretation procedure should be performed by the choice of several lines characteristic for a given spectral range. As shown in Fig. 1, the first procedure (after opening the image file being processed) for digital image processing is the - of the measuring coordinate system (pixel) to the photographic (experimental) one. This is done as follows: the wavelengths for two reference spectral lines in $\mathrm{nm}$ are entered into the corresponding widgets ("reference lines") of the OSA application, and the image indicates the coordinates of these lines in pixels, which allows to enter a horizontal scaling factor.

In our case, the experimental system for obtaining photographic films of glow is characterized by a graduated nonlinear scale connecting the values of the line position on the spectrum with the wavelength of the line in $\mathrm{nm}$. In the available wavelength range for the reference lines on the abscissa scale using the cubic interpolation method, the corresponding values are found on the ordinate scale in millimeters. Further, for an arbitrary line on the digital image of the spectrum, it is possible to determine the corresponding value in $\mathrm{mm}$, and automatically determine its wavelength in $\mathrm{nm}$ using inverse interpolation.

Fig. 1 shows the result of processing several spectral lines with different wavelengths, represented by vertically placed digits below each of the processed lines in a digital image. To estimate the measurement error, a multiple measurement of the wavelengths of several spectral lines was made and the statistical estimation of the quality of the OSA application work was done: the error in average is in the range from 0.075 to $0.2 \mathrm{~nm}$, depending on the distance of the measured line from the first reference line. Each of these lines is characterized (the graph at the top right) by the intensity distribution $\mathrm{I}[\mathrm{x}, \mathrm{y}]$. The distribution of the intensity of the spectral line along its height allows us to obtain the distribution of excited particles along a direction parallel to the axis of the magnetron discharge, since the intensity is proportional to the number of excited particles.

When a certain number $\mathrm{N}$ is entered into the "Number of points on a line" widget, a mathematical procedure is implemented to automatically calculate points along the selected line while simultaneously determining the intensity of each point. It should be noted that due to the peculiarities of the experiment when using optical lenses, the lines have curvature. This required the introduction of a piecewise linear approximation of points into the calculation. Schematically, the calculation algorithm is presented in Fig. 2,a. 
On the image of the line the first and last points of the track are manually drawn. This selects the area of digitization and determines the direction of movement. A priori, the points studied are between manually set points. Therefore, the experimental point 1 coincides with first. Between the points first and last a straight line is drawn and with a certain step an auxiliary point 2 'is automatically drawn on it. A prism spectrometer is used in the experiment, so that the spectral lines are always located on the left side of the straight line connecting the beginning of the line with its end. A vector is drawn from the auxiliary point 2 towards the line (in Fig. 2,a, an arrow from right to left) along the ordinate axis. It is considered that the maximum value of the intensity among the pixels of this vector corresponds to the coordinate of the center of the line. Thus, the experimental point 2 is determined. Between points 2 and last, a new straight line is drawn and at some distance the next auxiliary point 3 is plotted. The vector is drawn again and the coordinate of point 3 is found for the maximum value of the intensity. And so on, in the automatic cycle, for the required number of points $\mathrm{N}$.

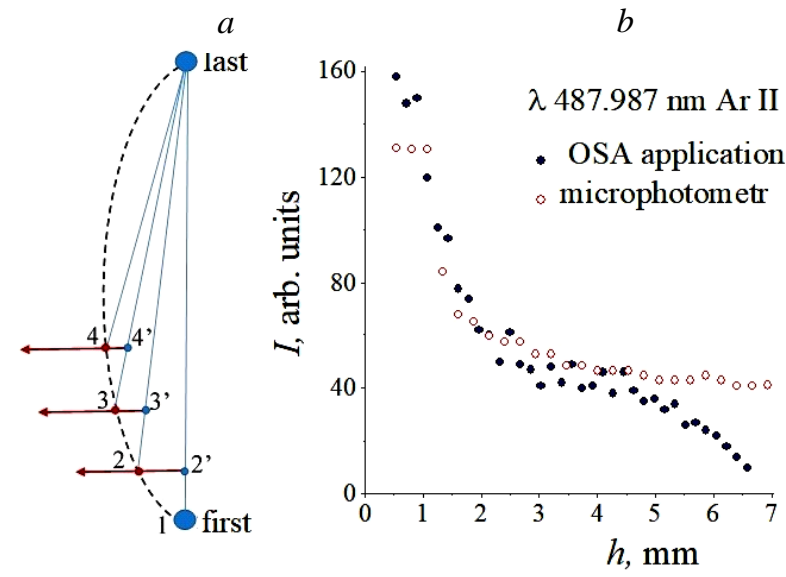

Fig. 2. The algorithm for determining the intensity of the glow at the points along the line (a); comparison of the intensity distributions obtained by the digital method and the method of photographic photometric measurement $(b)$

The points obtained in this way $(2,3$, 4, etc.) satisfactorily describe the trajectory of the line. The formed set of points is fitted by a 2 nd order polynomial - the function $y=a+b \cdot x+c \cdot x^{2}$. For certain coefficients $a$, $\mathrm{b}$, and $\mathrm{c}$, the coordinates of the required points $\mathrm{N}$ are calculated. The coordinates of the points and the intensity at each point are recorded in a separate external file and reproduced in the image of the OSA application. The result of the work of such an algorithm is shown in Fig. 1 by dots.

Points which are on Fig. 1 between the line and the digital vertical value of the wavelengths are plotted automatically at the same distance from the first point and allow you to determine the value of the background intensity of the image. When determining the distribution of the intensity of the glow, the correction to the background value is introduced. Each line has its own background value.
The program has the ability to simultaneously determine the characteristics of several lines. This allows you to compare visually the intensity distributions along the lines, as shown in Fig. 1 on the chart. For easy identification and comparison of information about different lines, the corresponding values are separated by color.

The obtained characteristics (wavelengths of spectral lines) allow us to begin the procedure of spectral lines interpreting. In a separate widget (between the image and the graph), lines of elements of the periodic system that are close in wavelengths are offered for selection. When initiating (marking) a corresponding position or several positions, a database of spectral lines for the corresponding element is automatically loaded (separate spreadsheets [1]). For any spectral line, the row includes 3 elements: directly the wavelength of the line, the excitation energy and the intensity of this line.

An algorithm has been developed that allows for each experimentally determined wavelength of a single line (see vertically placed figures in Fig. 1), to determine the most likely value from the table of spectral lines. By a simple comparative enumeration, the interval of values in the table, in which one of the experimental values falls, is fixed. Among the two limiting values, the one with the lower excitation energy is selected. In case of equality in this parameter, the third element is used: intensity. The preference is given to the option with the maximal intensity.

In the case of the competition of several elements of the periodic system, an algorithm of successive reduction of information is realized. First, for each individual element, the optimum alternative is chosen, and then from the selected options of elements, an absolutely optimum alternative is chosen.

To check the validity of the created application, a comparison of the results obtained both by the method of photographic photometry [4] and using the OSA application was made. The results of comparison are presented in Fig. 2,b for one of the arbitrarily selected spectral lines. The line characterizing the excited argon ions was processed using a MF-2 microphotometer (closed points) and the developed OSA application (open points). As can be seen from the figure, there is a qualitative agreement of the results. A significant deviation is observed only in the region of a weak signal. This is due to the decrease in the sensitivity of the microphotometer in this area, while the digital method allows expanding the range of intensity measurements.

It can be seen that the distribution of excited argon atoms in the discharge is a complex function of the distance to the target. In addition, depending on the operating mode of the magnetron, the relative intensity of the lines under study varies greatly [6]. This change may be different for particles excited in states with different excitation energies. This is most likely due to the different excitation efficiency of the upper state of the analyzed transition in the atom by the electrons of the ionization zone of the discharge plasma. In this regard, only the use of the photographic method of recording and further digital processing of the emission spectra allows one to perform both a methodical 
analysis of the magnetron discharge physics and a rapid analysis of the elemental composition of solids.

\section{CONCLUSION}

To solve the actual problem of the analysis of the sputtered particles radiation of during coating deposition in a magnetron sputtering system, a digital technique was proposed for processing the emission spectra of the discharge plasma. An OSA graphical application has been created, which allows to obtain qualitative and quantitative characteristics of magnetron discharge plasma.

Algorithms, which allow determining the wavelength of a specific spectral line and the distribution of radiation intensity along its height, have been developed. Analysis by wavelength allows identifying the charge and energy state of the excited particles that makes it possible with a high probability to determine the elemental composition of the discharge plasma. The distribution of the radiation intensity along the height of the spectral line gives information about the distribution of excited particles along a direction parallel to the axis of the magnetron discharge. This allows to control the mode of operation of the discharge and, as a consequence, the properties of the applied coatings.

\section{REFERENCES}

1. Yeon Sik Jung, Ji Yoon Seo, Dong Wook Lee, Duk Young Jeon. Influence of DC magnetron sputtering parameters on the properties of amorphous indium zinc oxide thin film // Thin Solid Films. 2003, v. 445, p. 63-71.

2. M. Gaillard, N. Britun, Yong M. Kim, and Jeon G. Han. Titanium density analysed by optical absorption and emission spectroscopy in a dc magnetron discharge // J. Phys. D: Appl. Phys. 2007, v. 40, p. 809-817.

3. И.В. Блонский, А.А. Гончаров, А.В. Демчишин и др. Исследование оптических характеристик цилиндрического газового разряда магнетронного типа в условиях синтеза пленок нитрида титана // ЖТФ. 2009, т. 79, с. 128-132.

4. V.S. Burakov, A.A. Yankovskii. Practical Handbook on Spectral Analysis. Oxford: "Pergamon", 1964, 204 p.

5. J. Feuchtwanger, V. Etxebarria, J. Portilla, J. Jugo, I. Badillo, I. Arredondo. Hydrogen electron cyclotron resonance ion sources plasma characterization based on simple optical emission spectroscopy // Nuclear Instruments and Methods in Physics Research Section A. 2018, v. 881, p. 44-47.

6. I.A. Afanasieva, V.V. Bobkov, V.V. Gritsyna, Yu.E. Logachev, I.I. Okseniuk, A.A. Skrypnyk, D.I. Shevchenko. On excited particle formation in crossed ExH fields // Vacuum. 2018, v. 149, p. 124-128.

7. Mark Lutz. Learning Python. Sevastopol: "O'Reilly Media". 2013, 1648 p.

8. A.A. Goncharov, A.N. Evsyukov, E.G. Kostin, E.K. Frolova. Study of nanocrystalline titanium dioxide film synthesis in a magnetron-type discharge by monitoring its optical and plasmodynamic characteristics // Ukr. J. Phys. 2010, v. 55, p. 677-684.

Article received 21.03.2019

\title{
ЦИФРОВАЯ ОБРАБОТКА ОПТИЧЕСКИХ СПЕКТРОВ ИЗЛУЧЕНИЯ ПЛАЗМЫ МАГНЕТРОННО-РАСПЫЛИТЕЛЬНОЙ СИСТЕМЫ
}

\author{
И.А. Афанасьева, С.Н. Афанасьев, Н.А. Азаренков, В.В. Бобков, В.В. Грицына, Ю.Е. Логачев, \\ И.И. Оксенюк, А.А. Скрипник, Д.И. Шевченко, В.М. Черноус
}

Для решения актуальной задачи, связанной с анализом свечения распыляемых частиц при нанесении покрытий в магнетронно-распылительной системе, была предложена цифровая методика обработки спектров излучения плазмы разряда. Создано графическое приложение OSA, позволяющее получить качественные и количественные характеристики плазмы магнетронного разряда. Полученная информация о распределении возбужденных частиц вдоль направления, параллельного оси магнетронного разряда, позволяет контролировать режим работы разряда и, как следствие, свойства наносимых покрытий.

\section{ЦИФРОВА ОБРОБКА ОПТИЧИНХ СПЕКТРІВ ВИПРОМІНЮВАННЯ ПЛАЗМИ МАГНЕТРОННО-РОЗПИЛЮВАЛЬНОЇ СИСТЕМИ}

\section{І.О. Афанасьєва, С.М. Афанасьєв, М.О. Азарєнков, В.В. Бобков, В.В. Грицина, Ю.С. Логачов, I.І. Оксенюк, А.О. Скрипник, Д.І. Шевченко, В.М. Чорноус}

Для вирішення актуального завдання, пов'язаного з аналізом світіння розпилених частинок при нанесенні покриттів у магнетронно-розпилювальній системі, була запропонована цифрова методика обробки спектрів випромінювання плазми розряду. Створено графічний додаток OSA, що дозволяє отримати якісні та кількісні характеристики плазми магнетронного розряду. Отримана інформація про розподіл збуджених частинок вздовж напрямку, паралельного осі магнетронного розряду, дозволяє контролювати режим роботи розряду i, як наслідок, властивості нанесених покриттів. 